\title{
Human and Social Capital Development for Self Efficacy of University Graduates: Bases for Development of Society
}

\author{
Dr. Shoukat Ali Raza \\ Assistant Professor, IER-University of the Punjab, Lahore, Pakistan
}

Dr. Shahid Zia

Chairman, Media, MARCON; Council Member, Marketing Association of Pakistan, Lahore, Pakistan

E-mail: lahorelse@yahoo.com

Syed Abir Hassan Naqvi

Lecturer, Dept. Of Technology

IER-University of the Punjab-Lahore, Pakistan

Faiz. M. Shaikh

Assistant Professor, SZABAC, Dokri, Larkana, Pakistan

E-mail: faizmuhammed_2000@yahoo.com

Received: April 2, $2011 \quad$ Accepted: May 17, $2011 \quad$ doi:10.5539/ass.v7n9p244

\begin{abstract}
The study investigated perceptions of students and employers about the development of human and social capital in terms of intellectual development skills, personal development skills, professional development skills, and social development skills for self efficacy of university graduates. How students and employers were viewing the development of human and social capital for self efficacy of university graduates; which areas of development skills were relatively stronger; and which sectors of industry or discipline of study were more satisfied or worried about were the questions answered in the study. Students of 4 public and 4 private universities and managers of 65 companies from 12 sectors of industry listed with Lahore Stock Exchange constituted the sample. Data were collected through an adopted, 30-item survey scale which was found reliable at 0.930 Cronbach's alpha. Mean scores and correlations were calculated for the four sub-scales. One-Sample t-test, Independent samples t-test, and one-way ANOA were employed for significance and variance analysis. The study concluded that students and employers were not fully satisfied with the development of human and social capital for self efficacy of university graduates. Intellectual development skills got the highest position whereas personal development skills were found at the lowest position. Professional and social development skills were found in the middle. This situation reflects performance of universities below standards and speaks of under utilization of their potential for contributing to the development of society. Serious initiative for the development of human and social capital for self efficacy of university graduates was the major recommendation.
\end{abstract}

Keywords: Human capital, Social capital, Self efficacy, Development of society

\section{INTRODUCTION}

The success or failure of graduates in practical life reflects individual and collective characteristics categorized as their human capital, social capital and self efficacy for which universities may be held responsible.

Human capital is a key factor of production which increases the employability in the job market (Son, 2010) as it is the reflection of cognitive ability of individuals that helps them understand and implement technologies in job activities (Hanushek \& Kimko, 2000) and results in greater competitiveness and performance of employees and employers (Agarwala, 2003: Marimuthu, Arokiasamy, \& Ismail, 2009). It may be taken as the knowledge, skills, and other attributes of individuals that enhance their productivity and earnings (Organization for Economic 
Cooperation and Development 1998; Schuller, 2000; Son, 2010) that ultimately causes growth of productivity and wealth of the society (Schuller, 2000; Son, 2010) in terms of GDP (Son, 2010). This potential for growth and survival (Manolova et al., 2002) could be generated through education, training and other professional initiatives. Garavan et al. (2001) summarized human capital attributes as creation of individual flexibility and adoptability; enhancement of individual competencies; increasing individual employability; and causing organizational survival. It focuses on individual agent; measures schooling duration and qualifications; provides productivity, income, health and civic activity as its outcomes; and models linear representation (Schuller, 2000).

After the description of human capital, now comes social capital. Social capital as introduced by Hanifan (1916) to explain the importance of community participation in enhancing school performance, means "shared norms or values that promote social cooperation" (p. 29) between two or more individuals for common ends (Fukuyama, 2002). The author reported that the concept of social capital could not get much popularity and vanished from the scene. However, it reentered the social science glossary in the 1980s. Social capital is produced through professional education as its byproduct; religion, history and globalization; social rules and norms; public goods such as property rights and public safety; and private sector or civil society growth (Fukuyama, 2001; 2002). It causes the realization of human capital's potential through relationships between different groups as well as within groups (Schuller, 2000) by reducing the transaction costs of contracts through coordination among a group of people possessing no social capital (Fukuyama, 2001).

Social capital is a key element in both economic development and stable democracy (Fukuyama, 2002) as networks open doors for entrepreneurs by "providing market access, financing, distribution channels, referrals and a pool of contacts for both internal and external development" (Coviello 2006: 723). Adler and Kwon (2002) a positive impact of social capital on job search, career success, inter-unit resource exchange, entrepreneurship, supplier relations, regional production networks, and inter-company learning. It could also produce positive externalities in people through teaching of social virtues like honesty, reciprocity, and dependability (Fukuyama, 2002). It focuses on relationships; measures attitudes/values, participation and trust levels; provides social cohesion, economic achievements and more social capital as its outcomes; and models interactive/circular representation (Schuller, 2000).

The description of human and social capital establishes that these are actually the skills, demanded for entry in the job market and success on the job, to be acquired through university education which is considered to be the main source for acquiring such skills. Students, therefore, are taking university education as a way to job market (Lawrence \& Sharma, 2002) and demand knowledge that meets world-wide job standards (Nagy, 2006). Responding to this demand, universities are restructuring their processes accordingly (Sohail \& Daud, 2006) as students are motivated to select only those universities which fulfill this demand (Song-Ae, 2005) and are developing and applying specific quality standards (LeBlanc \& Nguyen, 1997; Dinham, 2006) in teaching learning process (Seah \& Edward, 2006) such as identified in Education Sector Reforms Action Plan 2001-2004 (Government of Pakistan, 2001) in order to position their product in international markets (Seah \& Edward, 2006). Universities are under pressure to provide quality education (Mishra, Koehler, \& Zhao, 2007) to meet the demand of stakeholders (Higgs, 2007). The quality of higher education characterized with the human and social capital of students, is being measured through their generic skills or "range of qualities and capacities" (Hager, Holland, \& Backett, 2002:2) categorized as intellectual development skills, personal development skills, professional development skills, and social development skills (Raza, Majid, \& Zia, 2010) necessary for getting jobs and causing societal growth. The development of human and social capital leads to the development of self efficacy of the students which is described below.

Self efficacy is the belief about potential to achieve desired outcomes (Bandura, 1994, 1997; Maddux \& Gosselin, 2003). Maddux and Gosselin (2003) delimited self efficacy as not competencies, skills and abilities; simply predictions about behavior; intentions to behave or attain desired goals; outcome expectations; perceived control; causal attributions; self-esteem; and traits to make the concept clearer.

Self efficacy may be developed through four ways (Bandura, 1994; Luthans, Luthans, \& Luthans, 2004) namely mastery experiences or performance attainment--- the success stories; vicarious experiences provided by social models---watching people with similar characteristics; Social persuasion---getting motivated; and physiological and psychological arousal---reducing stress reactions. The authors described self efficacy as positive psychological capital that focuses on strengths rather than weaknesses, health and vitality rather than illness and pathology. They established that traditional economic capital (what you have i.e. finances and other tangibles) generates human capital (what you know i.e. knowledge, skills, and experience) that leads to the development of social capital (who you know i.e. networks of contacts) which results in positive psychological capital (who you are i.e. confidence, hope, optimism). 
The university faculty, again is supposed to guide students apply these models to make them confident players and successful members of community as students in higher education institutions struggle to map their professional identities (Hamel \& Ryken, 2010). They can play their role in developing human and social capital and self efficacy of students which are attributes of students' development (Luthans, Luthans, \& Luthans, 2004; Coviello 2006; Son, 2010) necessary for economic and social development of the society (Devlina \& Samarawickremab, 2010).

Emphasizing the value of human and social capital and self efficacy of university graduates, the current study was designed to investigate perceptions of students and employers about the development of human and social capital in terms of intellectual development skills, personal development skills, professional development skills, and social development skills for self efficacy of university graduates; compare these perceptions of students and employers in terms of gender; sector of industry; designation; qualification; experience of managers; respondents; discipline of study; sector of universities; and universities. To pursue these objectives, the study answered these questions:

1. What are perceptions of students and employers about the development of human and social capital in terms of intellectual development skills, personal development skills, professional development skills, and social development skills for self efficacy of university graduates?

2. Is there any significant difference in the perceptions of students and employers about the development of human and social capital in terms of intellectual development skills, personal development skills, professional development skills, and social development skills for self efficacy of university graduates? and

3. Is there any significant difference in the perceptions of students and employers about the development of human and social capital for self efficacy of university graduates in terms of gender; sector; designation; qualification; and experience as independent variables?

\section{METHODOLOGY}

The study is based on primary data collected from the students studying at master level in 08 ( 04 public and 04 private) universities of Lahore, Pakistan, affiliated with Higher Education Commission. A multistage sampling technique was employed. At first, $40 \%$ stratified random sampling was used to select 3.6 (i.e. 4 ) out of nine public universities and 4.4 (i.e. 4) out of eleven private universities to ensure the same proportion of sample as it was in the population. At the next stage, one-third (14) faculties were randomly selected from (41) available faculties of sample universities. Then, one-third (32) departments were randomly selected from (85) available departments of sample faculties of the sample universities. At the end, a spectrum of 800 students, 25 from each sample department, constituted the sample as given in table 1. The public-private split was 650 and 150 students.

\section{Insert Table 1 Here}

The second component of the sample was built by 65 managers from 188 randomly selected companies taken from 12 sectors of industry out of 37 listed sectors (Lahore Stock Exchange, 2010).

Raza, Majid, and Zia (2010) used a scale built on 30 employability skills and reported its four significant factors namely intellectual development skills (10 items), personal development skills (9 items), professional development skills ( 8 items), and social development skills (3 items) generated through principal component factor analysis. They reported the Cronbach's alpha reliability of the instrument as 0.9481 . These skills were revisited by a panel of four corporate mangers having more than five years of university teaching experience along with the researchers (Henderson-King \& Smith, 2006) and found them really translating human capital, social capital and self efficacy of university graduates. Therefore, the same instrument was adopted for the purpose of this study and found reliable at 0.930 Cronbach's alpha.

Data were collected by the third and fourth researchers during March 2010. The responses were quantified as 5 for strongly agree; 4 for agree; 3 for partially agree; 2 for disagree; and 1 for strongly disagree over the development of human and social capital in terms of intellectual development skills, personal development skills, professional development skills, and social development skills for self efficacy of university graduates. Taking mean score 3.0 (Aksu, 2003) as the cut point, mean scores significantly above 3.0 were taken as representing respondents' agreement over the development of human capital, social capital and self efficacy of university graduates. Whereas mean scores 3.0 and below were taken as representing respondents' disagreement over the development of human capital, social capital and self efficacy of university graduates.

Mean scores and correlations were calculated for factors of the scale. One-sample $t$-test, independent samples $t$-test and one-way ANOA were employed for significance and variance analysis. 


\section{FINDINGS}

The respondents included 800 students and 55 managers divided as 298 (256 students; 42 managers) males and 557 (544 students; 13 managers) females. Response rate remained $100 \%$ for students and $85 \%$ for managers. The discipline distribution of students revealed 400 respondents from social sciences; 150 from business; 150 from medical; 50 from IT; and 50 from languages. Mangers were from Sugar, 9; Banking, 8; Food, 7; Cement, 6; Auto, 5; Leasing, 4; Synthetics, 4; Glass \& Ceramics, 3; IT, 3; Oil \& Gas, 2; Paper \& Board, 2; and Tobacco, 2. Among these 12 were operation managers; 9 production managers; 8 finance managers; 8 HR managers; 7 marketing managers; 6 accounts managers; and 5 quality managers. The qualification split of these managers was as 10 master and 45 graduate degree holders. Among these, 12 mangers possessed 0-5 years; 24 held 6-10 years; 12 had 11-15 years; and 7 were having above 15 years of work experience.

The correlations found between intellectual development skills, personal development skills, professional development skills, and social development skills as factors and the whole scale are given in table 2 .

\section{Insert Table 2 Here}

Table 2 indicates that the correlations between factors are weak as compared against their correlations with the whole scale for development skills and this relationship reflects the uniqueness of these factors and strong participation in the whole scale. These findings too establish the validity of the instrument for the purpose of this study.

Despite the difference of opinion among the respondents, their collective opinion is found inclined towards the agreement over the development of human and social capital in terms of intellectual development skills, personal development skills, professional development skills, and social development skills for self efficacy of university graduates as revealed by combined mean scores for the four factors (table 3) that range from 3.734 to 3.850 .

\section{Insert Table 3 Here}

The table 3 shows mean scores for students and employers falling above the rejection region (03) but below the complete agreement level (04). In this state of affairs, intellectual development skills (3.850) getting the highest position whereas personal development skills (3.734) factor gets the lowest position. Professional development skills (3.765) and social development skills (3.763) are almost at same position in the middle. The alpha values for all the factors are above 0.6 that further validate the instrument.

Analysis of the open-ended question revealed that only 17 managers, out of 55, responded in three coded categories. Nine mangers highlighted deficiency in market exposure; six mangers pointed out lack of adoptability; and two managers outlined the inflexibility of university students.

Similarly, analysis of the background variables such as gender; sector of industry; designation; qualification; and experience of managers revealed no significant difference of opinion among the respondents over the development of human and social capital in terms of intellectual development skills, personal development skills, professional development skills, and social development skills for self efficacy of university graduates. However, other categories such as respondents; discipline of study; sector of universities; and universities themselves marked significant differences as given below.

\section{Insert Table 4 Here}

Table 4 points out employers as less satisfied when compared with students over the development of human and social capital in terms of intellectual development skills, professional development skills, and social development skills for self efficacy of university graduates. However, there was no significant difference of opinion between them over personal development skills.

\section{Insert Table 5 Here}

Table 5 points out private sector performing better as compared with pubic sector universities as a whole.

\section{Insert Table 6 Here}

Table 6 points out significant difference of opinion among the students of different fields of study over the development of human and social capital for self efficacy of university graduates in terms of development skills. The Tukey's HSD post hoc test for variance revealed weak position of social sciences against all other disciplines in all the four areas of development skills. Medical was found strong against all other disciplines in personal development skills and against social sciences and business in professional and social development skills. Otherwise there was no significant difference of opinion among students of social sciences; business; medical; IT; and languages. 


\section{Insert Table 7 Here}

Table 7 indicates significant difference of opinion among the students of sample universities over the development of human capital, social capital for self efficacy of university graduates in terms of development skills. The Tukey's HSD post hoc test for variance revealed KEMU relatively better in all categories of development skills. The position of other newly established public sector universities was found weak against private and old public universities. PU had no significant difference with LUMS in intellectual and social development skills and with KEMU in intellectual development skills. Otherwise, there was no significant difference of opinion among the students of sample universities.

\section{DISCUSSION}

The current study pursued three basic questions. The first one was regarding the perceptions of students and employers about the development of human and social capital in terms of intellectual development skills, personal development skills, professional development skills, and social development skills for self efficacy of university graduates. The mean scores for intellectual, personal, professional and social development skills are inclined towards the agreement of the respondents over the development of human and social capital for self efficacy of university graduates. But this agreement is weak as all the means are below 4.0 that reflect the situation where students and employers are not fully satisfied over the principal attributes of university graduates. It means that universities are performing below the job market standards. A possible cause of this trend may be the underperformance of university faculty in imparting these development skills to help students fulfill the job market needs and contribute towards the development of the society. These results are consistent with Song-Ae (2005), Sohail and Daud (2006), Coviello (2006), Higgs (2007), Marimuthu, Arokiasamy, and Ismail (2009), Devlina and Samarawickremab (2010), Hamel and Ryken (2010) and Son (2010) providing answer to the first research question that leads to the of first objective of the current study.

The second dimension of the study was the significant difference in the perceptions of students and employers about the development of human and social capital in terms of intellectual development skills, personal development skills, professional development skills, and social development skills for self efficacy of university graduates. These sub-scales have been found significant with alpha values $(0.902),(0.737),(0.809)$, and $(0.641)$ respectively (Gursoy \& Umbreit, 2005) for the purpose of this study. The correlations within these factors were weak and correlations of these factors with overall scale were strong that further enhance their significance (Morgeson, \& Humphrey, 2006). Intellectual development skills include generation and understanding of new knowledge, using and disseminating the same with confidence; personal development skills cover continuous self-growth and confidence; professional development skills mean the demonstration of entrepreneurial abilities for innovation and creativity and performance at work place; and social development skills emphasize commitment to social justice, exhibition of approved mannerism, and service of the community as the basic requirements of the profession (University of Sydney, 2004; Truckee Meadows Community College, 2007).

The findings of the study prioritized intellectual development skills (3.850); professional development skills (3.765); social development skills (3.763); and personal development skills (3.734) at first, second, third, and fourth position respectively as perceived by students and employers. It means that though students and employers were not fully satisfied with the development of human and social capital for self efficacy of university graduates (Song-Ae, 2005; Zieber, 2006; Higgs, 2007; Tierney, 2008; Doyle, 2008), they perceived that intellectual development skills of graduates were comparatively better. Their opinion about professional and social development skills were almost at same level whereas they placed personal development skills of university graduates at lowest level. One possible reason of this situation might be indifferent attitude of faculty to develop personal skills of their studetns (Lawrence \& Sharma, 2002). Professional and intellectual development skills need more faculty intervention as these are below the desirable level (Hager, Holland, \& Backett, 2002). The situation with social development skills needs special consideration as it reflects weak social interactions between faculty and students (Sahu, 2002; Gabriel, 2008). In this way the study provided answer to the second question.

Similarly, the third aspect of the study was to explore the significant difference in the perceptions of students and employers about the development of human and social capital for self efficacy of university graduates in terms of gender; sector; designation; qualification; and experience as independent variables.

Analysis of the background variables such as gender; sector of industry; designation; qualification; and experience of managers revealed no significant difference of opinion among the respondents over the development of human and social capital for self efficacy of university graduates. This tendency reflects the same mind set in all these categories over the unsatisfactory state of affairs. However, other categories such as 
respondents; discipline of study; sector of universities; and universities themselves marked significant differences among the respondents.

Employers are less satisfied as compared with students over the development of human and social capital for self efficacy of university graduates. However, there was no significant difference of opinion between them over personal development skills. Private sector is found performing better as compared with pubic sector as a whole. The weak position of social sciences against all other disciplines in all the four areas of development skills is evident. Medical is found strong against all other disciplines in personal development skills and against social sciences and business in professional and social development skills. This tendency gets support also from the university analysis where KEMU is relatively better in all categories of development skills. No significant difference of opinion is found among students of social sciences; business; medical; IT; and languages. It means that they all are equally dissatisfied. The position of certain newly established public sector universities is found weak against private and old public universities and this tendency may reflect their weak systems. PU has no significant difference with LUMS in intellectual and social development skills and with KEMU in intellectual development skills. This tendency could be taken as healthy sign and may speak of the commitment of PU quality assurance. These perceptions of students and employers provide answer to the third and last question of the study.

Analysis of the open-ended question also revealed lack of market exposure, adoptability, and flexibility in the graduates that shook further the confidence of employers. These findings are consistent with Song-Ae (2005), Zieber (2006), Higgs (2007), Tierney (2008), and Doyle (2008). This situation speaks of relative inability of universities in playing their mandatory roles (Zieber, 2006; Doyle, 2008; Tierney, 2008), required to inculcate development skills in the students to make them fit for the job markets.

\section{CONCLUSION}

Students and Employers were not fully satisfied over the development of human and social capital in terms of intellectual, professional, personal, and social development skills for self efficacy of university graduates. This situation reflects performance of Pakistani universities below the standards of job market in preparing quality graduates. This issue of sub-standard quality of human and social capital for self efficacy of university graduates becomes more complex when they go to compete in international job markets. This is not just a question of satisfaction of students and employers; it is also a description of potential weakness of Pakistani universities for contributing to the economic and social development of country which is their mandatory role as laid down in the National Education Policy and this situation creates a difficult position of the educational leaders to account for the heaviest investment of government in higher education sector.

\section{RECOMMENDATIONS}

The current study provided bases for recommending Pakistani universities to revisit their teaching learning processes and take appropriate measures for improvement upon the unsatisfactory state of human and social capital development for self efficacy of their graduates. They need to focus on their mandatory roles in preparing quality graduates for job markets to realize the national higher education objectives for materializing the dream of nation for development of Pakistani society.

The government of Pakistan is heavily investing in higher education and universities should ensure at least return of investment if they are not in a position to ensure return on investment. Appropriate human resource policies such as continues faculty development and students' evaluation of faculty should be made a regular feature of Pakistani universities to produce quality graduates who could better contribute to the development of society.

\section{References}

Adler, Paul S., and Seok-Woo Kwon. (2002). Social capital: Prospects for a new concept. Academy of Management Review, 27(1), 17-40. doi:10.5465/AMR.2002.5922314, http://dx.doi.org/10.5465/AMR.2002.5922314

Agarwala, T. (2003). Innovative human resource practices and organizational commitment: An empirical investigation. International Journal of Human Resource Management, 14(2), 175-197. doi:10.1080/0958519021000029072, http://dx.doi.org/10.1080/0958519021000029072

Aksu, M. B. (2003). TQM readiness level perceived by the administrators working for the central organization of the Ministry of National Education in Turkey. Total Quality Management \& Business Excellence, 14(5): 595-608. doi:10.1080/1478336032000053609, http://dx.doi.org/10.1080/1478336032000053609

Bandura, A. (1994). Self-efficacy. In V. S. Ramachaudran (Eds.). (1998). Encyclopedia of human behavior (Vol. 
4, pp. 71-81). New York: Academic Press.

Bandura, A. (1997). Self-efficacy: The exercise of control. W.H. Freeman (New York). 42-50.

Coviello, N. E. (2006). The network dynamics of international new ventures. Journal of International Business Studies, 37(5): 713-731.

Devlina, M. \& Samarawickremab, G. (2010). The criteria of effective teaching in a changing higher education context. Higher Education Research \& Development, 29(2): 111-124. doi:10.1080/07294360903244398, http://dx.doi.org/10.1080/07294360903244398

Dinham, S. (2006). A good teacher in every classroom, Book review [Article Excerpt]. Australian Journal of Education. [Online] Available: http://goliath.ecnext.com (July 14, 2007)

Doyle, W. (1986). Classroom organization and management. In M. Wittrock, (Ed.), Third Handbook of Research on Teaching (pp.392-431). New York: Macmillan.

Fukuyama, F. (2001). Social capital, civil society and Development. Third World Quarterly, 22(1): 7-20. doi:10.1080/713701144, http://dx.doi.org/10.1080/713701144

Fukuyama, F. (2002). Social Capital and Development: The Coming Agenda. SAIS Review, 22(1): 23-37. doi:10.1353/sais.2002.0009, http://dx.doi.org/10.1353/sais.2002.0009

Gabriel, K. F. (2008). Teaching Unprepared Students: Strategies for Promoting Success and Retention in Higher Education. Stylus Publishing.

Garavan, T. N., Morley, M., Gunnigle, P., \& Collins, E. (2001). Human Capital accumulation: The role of human resource development. Journal of European Industrial Training, 25(2/3/4): 48-68.

Government of Pakistan. (2001). Education Sector Reforms Action Plan 2001-2004. Islamabad: Ministry of Education.

Gursoy, D., \& Umbreit, W. T. (2005). Exploring students' evaluation of teaching effectiveness: What factors are important? Journal of Hospitality \& Tourism Research, 29(1): 91-109. doi:10.1177/1096348004268197, http://dx.doi.org/10.1177/1096348004268197

Hager, P., Holland, S., \& Backett, D. (2002). Enhancing the learning and employability of graduates: The role of generic skills. Melbourne: The Business/Higher Education Round Table.

Hamel, F. L. \& Ryken, A. E. (2010). Rehearsing professional roles in community: teacher identity development in a school-university partnership. Teacher Development, 14(3): 335-350. doi:10.1080/13664530.2010.504015, http://dx.doi.org/10.1080/13664530.2010.504015

Hanifan, L.J. (1916). The Rural School Community Centre. Annals of the American Academy of Political and Social Sciences, 67, 130-38. doi:10.1177/000271621606700118, http://dx.doi.org/10.1177/000271621606700118

Hanushek, E., and D. Kimko. (2000). Schooling, Labor Force Quality, and the Growth of Nations. American Economic Review, 90(5): 1184-208. doi:10.1257/aer.90.5.1184, http://dx.doi.org/10.1257/aer.90.5.1184

Henderson-King, D., \& Smith, M. N. (2006). Meanings of education for university students: academic motivation and personal values as predictors. Social Psychology of Education, 9(2): 195-221. doi:10.1007/s11218-006-0006-4, http://dx.doi.org/10.1007/s11218-006-0006-4

Higgs, P. (2007). What is Quality in Higher Education? [Online] Available: http://www.philosophy-of-ducation.org:443/conferences/pdfs/ Higgs\% 202007\%20PESGB.pdf (June 25, 2007)

Lahore Stock Exchange. (2010). Sector Wise OHLC. [Online] Available: http://www.lahorestock.com/MarketInformation/SectorWise.aspx (March 4, 2010)

Lawrence, S., \& Sharma, U. (2002). Commodification of education and academic labor: using the balanced scorecard in a university setting. Critical Perspectives on Accounting, 13(5/6): 661-667. doi:10.1006/cpac.2002.0562, http://dx.doi.org/10.1006/cpac.2002.0562

LeBlanc, G., \& Nguyen, N. (1997). Search for excellence in business education: an exploratory study of customer impressions of service quality. International Journal of Educational Management, 11(2): 72-79. doi:10.1108/09513549710163961, http://dx.doi.org/10.1108/09513549710163961

Luthans, F., Luthans, K. W., \& Luthans, B. C. (2004). Positive psychological capital:Beyond human and social capital. Business Horizons, 47(1): 45-50. doi:10.1016/j.bushor.2003.11.007, 
http://dx.doi.org/10.1016/j.bushor.2003.11.007

Maddux, JE \& Gosselin, JT. (2003). Self-efficacy. In M. R. Leary \& J. P. Tangney (Eds.), (2005). Handbook of Self and Identify, pp.218-238. New York: Guilford.

Manolova, T.S., Brush, C.G., Edelman, L.F. and Greene, P.G. (2002). Internationalization of Small Firms. International Small Business Journal, 20(1): 9-31. doi:10.1177/0266242602201003, http://dx.doi.org/10.1177/0266242602201003

Marimuthu, M., Arokiasamy, L. \& Ismail, M. (2009). Human Capital Development and Its Impact on Firm Performance: Evidence from Developmental Economics. The Journal of International Social Research, 2(8): $265-272$

Mishra, P., Koehler, M. J., \& Zhao, Y. (Eds.). (2007). Faculty Development by Design: Integrating Technology in Higher Education. Information Age Publishing.

Morgeson, F.P. \& Humphrey, S.E. (2006). The Work Design Questionnaire (WDQ): Developing and Validating a Comprehensive Measure for Assessing Job Design and the Nature of Work. Journal of Applied Psychology, 91(6): 1321-1339. doi:10.1037/0021-9010.91.6.1321, http://dx.doi.org/10.1037/0021-9010.91.6.1321

Nagy, J. (2006). Adapting to market conditions: plagiarism, cheating and strategies for cohort. Studies in Learning, Evaluation, Innovation and Development, 3(2): 37-47.

OECD. (1998). Human Capital Investment: An International Comparison. Paris: Organization for Economic Cooperation and Development, Centre for Educational Research and Innovation.

Raza, S. A., Majid, Z, and Zia, A. (2010). Perceptions of Pakistani University Students about Roles of Academics Engaged in Imparting Development Skills: Implications for Faculty Development. Paper accepted for publication in Bulletin of Education and Research, Institute of Education and Research, University of the Punjab, Lahore, Pakistan.

Sahu, A. (2002). Teaching Philosophy: On Some Aspects of Teaching Style. [Online] Available: http://faculty.coppin.edu/pagesasahu/philosophy_Teaching.html (July 7, 2007)

Schuller, T. (2000). Social and Human Capital: The Search for Appropriate Technomethodology. Policy Studies, 21(1): 25-35. doi:10.1080/014428700113991, http://dx.doi.org/10.1080/014428700113991

Seah, W. T., \& Edward, J. (2006). Flying in, flying out: offshore teaching in higher education [Article Excerpt]. Australian Journal of Education. [Online] Available: http://goliath.ecnext.com (July 14, 2007)

Sohail, M. S., \& Daud, S. (2006). Restructuring a higher education institution: A case study from a developing country. International Journal of Educational Management, 20(4): 279-290. doi:10.1108/09513540610665397, http://dx.doi.org/10.1108/09513540610665397

Son, H. H. (2010). Human Capital Development. ADB Economics Working Paper Series No. 225. Manila: Asian Development Bank.

Song-Ae, H. (2005). Good teachers know where to scratch when learners feel itchy: Korean learners' views of native-speaking teachers of English [Article Excerpt]. Australian Journal of Education. [Online] Available: http://goliath.ecnext.com (July 14, 2007)

Tierney, W. G. (2008). The Impact of Culture on Organizational Decision-Making: Theory and Practice in Higher Education. Stylus Publishing.

Truckee Meadows Community College (TMCC). (2007). General Education: Learning Outcomes and Assessment Handbook. [Online] Available: http://www.tmcc.edu/vp/aa/downloads/documents/ GenEdHandbook.pdf (August 23, 2007)

University of Sydney (USyed). (2004). Generic Attributes of Graduates of the University of Sydney (Academic Board Resolution). [Online] Available: http://www.itl/usyd.edu.au/GraduateAttributes/unipolicy.pdf (July 16, 2007)

Zieber, M. P. (2006). Tutor's Role. (NURS 3008-Introduction to Baccalaureate Nursing, School of Health Sciences, University of Lethbridge). [Online] Available: http://www.uleth.ca/hlsc/courses/nursing/ 3000/Nurs3008.pdf (July 5, 2007) 


\section{Annexure}

Dear respondent,

\section{QUESTIONNAIRE}

Universities are supposed to inculcate the following skills in students for developing their human and social capital for their self efficacy so that they could perform better at work place and contribute towards the development of society. Please read the skills given in four broader areas and encircle the most appropriate response options against them where $5=\mathrm{SA}$ (Strongly agree); $4=\mathrm{A}$ (agree); $3=\mathrm{PA}$ (Partially agree); $2=\mathrm{DA}$ (Disagree); and 1 = SDA (Strongly disagree).

\begin{tabular}{|c|c|c|c|c|c|}
\hline Development Skill & \multicolumn{5}{|c|}{ Rating Scale } \\
\hline Intellectual development skills (IDS) & $\mathbf{S A}$ & $\mathbf{A}$ & PA & DA & SDA \\
\hline Analytical ability & 5 & 4 & 3 & 2 & 1 \\
\hline Evaluation & 5 & 4 & 3 & 2 & 1 \\
\hline Knowledge development & 5 & 4 & 3 & 2 & 1 \\
\hline Diversity management & 5 & 4 & 3 & 2 & 1 \\
\hline Problem solving & 5 & 4 & 3 & 2 & 1 \\
\hline Critical thinking & 5 & 4 & 3 & 2 & 1 \\
\hline Assessment & 5 & 4 & 3 & 2 & 1 \\
\hline Knowledge management & 5 & 4 & 3 & 2 & 1 \\
\hline Learning & 5 & 4 & 3 & 2 & 1 \\
\hline Decision-making & 5 & 4 & 3 & 2 & 1 \\
\hline Personal development skills (PERDS) & $\mathbf{S A}$ & $\mathbf{A}$ & PA & DA & SDA \\
\hline Communication & 5 & 4 & 3 & 2 & 1 \\
\hline Teamwork & 5 & 4 & 3 & 2 & 1 \\
\hline Confidence & 5 & 4 & 3 & 2 & 1 \\
\hline Interpersonal affairs & 5 & 4 & 3 & 2 & 1 \\
\hline Information literacy & 5 & 4 & 3 & 2 & 1 \\
\hline Compare and contrast ability & 5 & 4 & 3 & 2 & 1 \\
\hline Workplace behavior & 5 & 4 & 3 & 2 & 1 \\
\hline Personality development & 5 & 4 & 3 & 2 & 1 \\
\hline Information and communication technology & 5 & 4 & 3 & 2 & 1 \\
\hline Professional development skills (PRDS) & SA & $\mathbf{A}$ & PA & DA & SDA \\
\hline Forecasting & 5 & 4 & 3 & 2 & 1 \\
\hline Conflict management & 5 & 4 & 3 & 2 & 1 \\
\hline Customer-service & 5 & 4 & 3 & 2 & 1 \\
\hline Fairness & 5 & 4 & 3 & 2 & 1 \\
\hline Leadership & 5 & 4 & 3 & 2 & 1 \\
\hline Job preparedness & 5 & 4 & 3 & 2 & 1 \\
\hline Professionalism & 5 & 4 & 3 & 2 & 1 \\
\hline Subject knowledge & 5 & 4 & 3 & 2 & 1 \\
\hline Social development skills (SDS) & $\mathbf{S A}$ & $\mathbf{A}$ & $\mathbf{P A}$ & DA & SDA \\
\hline Ethics & 5 & 4 & 3 & 2 & 1 \\
\hline Socialization & 5 & 4 & 3 & 2 & 1 \\
\hline Citizenship & 5 & 4 & 3 & 2 & 1 \\
\hline
\end{tabular}

Thank you very much for your time. 
Table 1. University-wise Students' Sample

\begin{tabular}{|c|c|c|c|c|c|c|}
\hline \multirow[b]{2}{*}{$\begin{array}{l}\text { Secto } \\
\quad r\end{array}$} & \multirow[b]{2}{*}{ Universities } & \multicolumn{2}{|c|}{ Faculties } & \multicolumn{2}{|c|}{ Departments } & \multirow[b]{2}{*}{$\begin{array}{l}\text { Stude } \\
\text { nt s }\end{array}$} \\
\hline & & Total & $\begin{array}{c}\text { Take } \\
\mathrm{n}\end{array}$ & Total & $\begin{array}{c}\text { Take } \\
\mathrm{n}\end{array}$ & \\
\hline $\mathrm{P}$ & University of the Punjab (PU) & 13 & 4 & 27 & 9 & 225 \\
\hline $\mathrm{U}$ & Lahore College for Women University (LCWU) & 4 & 1 & 17 & 6 & 150 \\
\hline B & Govt. College University (GCU) & 3 & 1 & 15 & 5 & 125 \\
\hline $\mathrm{L}$ & King Edward Medical University (KEMU) & 5 & 2 & 18 & 6 & 150 \\
\hline $\begin{array}{l}\mathrm{I} \\
\mathrm{C}\end{array}$ & Total public sector contribution & 25 & 8 & 77 & 26 & 650 \\
\hline $\begin{array}{l}\mathrm{P} \\
\mathrm{P}\end{array}$ & $\begin{array}{l}\text { Lahore University of Management Sciences } \\
\text { (LUMS) }\end{array}$ & 3 & 1 & 3 & 1 & 25 \\
\hline $\begin{array}{l}\text { K } \\
\end{array}$ & University of Central Punjab (UCP) & 5 & 2 & 2 & $2^{*}$ & 50 \\
\hline V & $\begin{array}{l}\text { University of Management and Technology } \\
\text { (UMT) }\end{array}$ & 3 & 1 & 1 & $1^{*}$ & 25 \\
\hline $\begin{array}{l}\text { A } \\
T\end{array}$ & Superior University (SU) & 5 & 2 & 2 & $2^{*}$ & 50 \\
\hline E & Total private sector contribution & 16 & 6 & 8 & 6 & 150 \\
\hline $\mathbf{L}$ & $\begin{array}{r}\text { Grand Total } \\
\end{array}$ & 41 & 14 & 85 & 32 & 800 \\
\hline
\end{tabular}

* Faculties based on single department

Table 2. Correlation of Factors with the Whole Scale for Development Skill

\begin{tabular}{lcccc}
\hline \multicolumn{1}{c}{ Factors } & $\begin{array}{l}\text { Personal } \\
\text { development } \\
\text { skills }\end{array}$ & $\begin{array}{l}\text { Professional } \\
\text { development } \\
\text { skills }\end{array}$ & $\begin{array}{l}\text { Social } \\
\text { development } \\
\text { skills }\end{array}$ & $\begin{array}{c}\text { Development } \\
\text { Skills }\end{array}$ \\
\hline Intellectual dev skills & $0.459\left(^{* *}\right)$ & $0.452(* *)$ & $0.456\left(^{* *}\right)$ & $.952\left(^{* *}\right)$ \\
Personal dev skills & & $0.321(* *)$ & $0.430(* *)$ & $.880\left(^{* *}\right)$ \\
Professional dev skills & & & $0.391(* *)$ & $.756\left(^{* *}\right)$ \\
Social dev skills & & & $.774\left(^{* *}\right)$ \\
\hline Correlation is significant at the 0.01 level (2-tailed).
\end{tabular}

Table 3. Alpha, Mean Scores and One-Sample t-Test for Development Skills

\begin{tabular}{lllcccc}
\hline Sub-Scales & Alpha & Respondent & $\mathrm{N}$ & Mean & SD & $t$-values \\
\hline \multirow{2}{*}{$\begin{array}{l}\text { Intellectual Development } \\
\text { Skills }\end{array}$} & \multirow{2}{*}{0.902} & Students & 800 & 3.885 & 0.775 & $30.832^{*}$ \\
\cline { 3 - 7 } & & Employers & 55 & 3.347 & 0.806 & $6.147^{*}$ \\
\cline { 3 - 7 } & & Total & 855 & 3.850 & 0.788 & $31.545^{*}$ \\
\hline \multirow{2}{*}{$\begin{array}{l}\text { Personal Development } \\
\text { Skills }\end{array}$} & \multirow{2}{*}{0.737} & Students & 800 & 3.743 & 0.585 & $35.906^{*}$ \\
\cline { 3 - 7 } & & Employers & 55 & 3.604 & 0.596 & $9.024^{*}$ \\
\cline { 3 - 7 } $\begin{array}{l}\text { Professional Development } \\
\text { Skills }\end{array}$ & \multirow{2}{*}{0.809} & Total & 855 & 3.734 & 0.587 & $36.588^{*}$ \\
\hline \multirow{3}{*}{ Social Development Skills } & \multirow{2}{*}{0.641} & Students & 800 & 3.792 & 0.624 & $26.334^{*}$ \\
\cline { 3 - 7 } & & Employers & 55 & 3.371 & 0.831 & $6.663^{*}$ \\
\cline { 3 - 7 } & & Sotal & 855 & 3.765 & 0.647 & $34.592^{*}$ \\
\cline { 3 - 7 } & Employers & 55 & 3.424 & 0.766 & $6.466^{*}$ \\
\cline { 3 - 7 } & Total & 855 & 3.763 & 0.712 & $31.330^{*}$ \\
\hline
\end{tabular}

$* p<0.05$ 
Table 4. Independent Samples t-test against Respondents for Development Skills Factors

\begin{tabular}{llrrrr}
\hline Sub-Scales & Respondents & N & Mean & SD & \multicolumn{1}{c}{$t$} \\
\hline \multirow{2}{*}{ Intellectual development skills } & Students & 800 & 3.885 & 0.775 & $4.959^{*}$ \\
\cline { 2 - 6 } & Employers & 55 & 3.347 & 0.806 & \\
\hline \multirow{2}{*}{ Personal development skills } & Students & 800 & 3.743 & 0.585 & 1.702 \\
\cline { 2 - 6 } & Employers & 55 & 3.604 & 0.596 & \\
\hline \multirow{2}{*}{ Professional development skills } & Students & 800 & 3.792 & 0.624 & $4.737^{*}$ \\
\cline { 2 - 6 } & Employers & 55 & 3.371 & 0.831 & \\
\hline \multirow{2}{*}{ Social development skills } & Students & 800 & 3.786 & 0.702 & $3.671^{*}$ \\
\cline { 2 - 6 } & Employers & 55 & 3.424 & 0.766 & \\
\hline
\end{tabular}
$* p<\overline{0.05}$

Table 5. Independent Samples t-test against Sector of Universities for Factors of Skills

\begin{tabular}{llcccc}
\hline Sub-Scales & Sector & $\mathrm{N}$ & Mean & SD & $t$ \\
\hline \multirow{2}{*}{ Intellectual development skills } & Public & 650 & 3.819 & 0.809 & $-5.103^{*}$ \\
\cline { 2 - 6 } & Private & 150 & 4.171 & 0.519 & \\
\hline \multirow{2}{*}{ Personal development skills } & Public & 650 & 3.695 & 0.615 & $-4.935^{*}$ \\
\cline { 2 - 6 } & Private & 150 & 3.953 & 0.370 & \\
\hline \multirow{2}{*}{ Professional development skills } & Public & 650 & 3.770 & 0.643 & $-2.136^{*}$ \\
\cline { 2 - 6 } & Private & 150 & 3.890 & 0.525 & \\
\hline \multirow{2}{*}{ Social development skills } & Public & 650 & 3.725 & 0.731 & $-5.215^{*}$ \\
\cline { 2 - 6 } & Private & 150 & 4.051 & 0.482 & \\
\hline
\end{tabular}
$* p<0.05$

Table 6. One way ANOVA against Discipline of Study for Development Skills Factors

\begin{tabular}{llrccc}
\hline Sub-Scales & Group & SS & MS & df & $F$ \\
\hline \multirow{2}{*}{ Intellectual development skills } & BG & 75.685 & 18.921 & 4 & $37.177^{*}$ \\
\cline { 2 - 6 } & WG & 404.616 & 0.509 & 795 & \\
\hline \multirow{2}{*}{ Personal development skills } & BG & 48.344 & 12.086 & 4 & $42.626^{*}$ \\
\cline { 2 - 6 } & WG & 225.408 & 0.284 & 795 & \\
\hline \multirow{2}{*}{ Professional development skills } & BG & 11.919 & 2.98 & 4 & $7.929^{*}$ \\
\hline \multirow{2}{*}{ Social development skills } & WG & 298.782 & 0.376 & 795 & \\
\hline
\end{tabular}
$* p<0.05$

Table 7. One way ANOVA against University for Development Skills Factors

\begin{tabular}{llcccc}
\hline Sub-Scales & Group & SS & MS & df & $F$ \\
\hline \multirow{2}{*}{ Intellectual development skills } & BG & 164.134 & 23.448 & 7 & $58.737^{*}$ \\
\cline { 2 - 6 } & WG & 316.167 & 0.399 & 792 & \\
\hline \multirow{2}{*}{ Personal development skills } & BG & 101.936 & 14.562 & 7 & $67.126^{*}$ \\
\cline { 2 - 6 } & WG & 171.816 & 0.217 & 792 & \\
\hline \multirow{2}{*}{ Professional development skills } & BG & 39.815 & 5.688 & 7 & $16.63^{*}$ \\
\hline \multirow{2}{*}{ Social development skills } & WG & 270.886 & 0.342 & 792 & \\
\hline & BG & 151.222 & 21.603 & 7 & $70.418^{*}$ \\
\cline { 2 - 6 } & WG & 242.973 & 0.307 & 792 & \\
\hline
\end{tabular}

